\title{
Ortaokul ve Liselerde Yaşanan Disiplin Problemlerinin Çözümüne Yönelik Yönetsel Uygulamalar ${ }^{1}$
}

\author{
Dr. Fatih Pehlivan \\ MEB-Türkiye \\ fatihpehlivan@yahoo.com
}

\author{
Doç. Dr. Hasan Demirtaş \\ Inönü Üniversitesi-Türkiye \\ hasan.demirtas@inönü.edu.tr
}

\section{Özet:}

Bu araştırmanın amacl; ortaokul ve liselerde disiplin sağlama adına yapılan uygulamaları ortaya koymaktır. Bu amaçla 25 yönetici bu araştırmanın katılımcı grubunu oluşturmaktadır. Araştırma verileri yöneticilerle yapılan yarı yapılandırılmış görüşmeler yoluyla toplanmıştır. Verilerin analizinde ise içerik analizi yapılmıştır. Araştırma bulguları ışı̆̆ında okul yöneticilerinin, disiplin sorunlarının yaşanması sürecinde önleyici destekleyici ve düzeltici uygulamaların etkili olabileceğini düşündüklerini anlaşılmaktadır. Araştırmada "önleyici disiplin yaklaşımı" temasına uygun görüşlerin ağırlıkta olduğu görülmektedir. Araştırma kapsamındaki okullarda görev yapan yöneticiler; disiplini sağlamak için en çok ögretmenlerin problem çözümünde işbirliği ve katkılarının sağlanması yaklaşımına ve olumsuz davranışla ilgili veliyi bilgilendirmeye başvurmaktadır.

Anahtar Sözcükler: Okul disiplini, Öğrenci disiplini, Disiplin Problemleri, Disiplin Problemlerinin Önlenmesi Yaklaşımları,

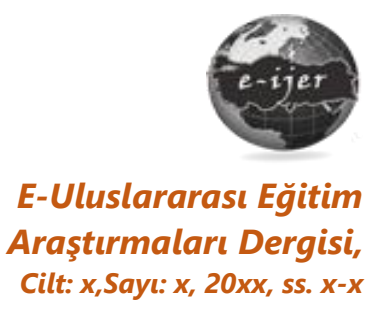

DOI: 10.19160/ijer.584206

\section{Önerilen Atıf}

Pehlivan, F. \&. Demirtaş, H. (2019). Ortaokul ve Liselerde Yaşanan Disiplin Problemlerinin Çözümüne Yönelik Yonetsel Uygulamalar, E-Uluslararası Eğitim Araştırmaları Dergisi, Cilt: 10, Sayı: 2, 2019, ss. 31-79, DOI: 10.19160/ijer.584206

\footnotetext{
${ }^{1}$ Bu çalışma birinci yazarın, ikinci yazar danışmanlığında tamamladığı doktora tezinden üretilmiştir.
} 


\section{GíRiş}

Insan sosyal bir varlıktır ve varlığını sürdürmek için çevresindekilerle sürekli etkileşim halindedir. Bu etkileşim sürecinde çatışmaların olması kaçınılmaz bir olgudur. Ürünü insan olan eğitim sistemlerinin amaci okullar yoluyla toplumu oluşturan bireylerin yetiştirilmesi ve bir arada yaşamanın gerektirdiği birtakım davranışları kazanmasını sağlamaktır. İstenmeyen, eğitimi aksatıcı özellik gösteren durumların oluşmasını önlemek ya da ortaya çıkabilecek disiplin sorunlarının çözümü için okullardaki süreçleri düzenleyecek kural ve yaptırımlara intiyaç duyulmaktadır. Eğitim-öğretim sürecinin etkililiği ve verimliliğinin sağlanması süreçlerin iyi yönetilmesini ve güçlü kurumsal bir kültürün varlığını gerektirmektedir.

Eğitime ilişkin birçok teori, düzenli bir öğrenme ortamı yaratarak öğrencilerin okuldaki başarılarını arttırmayı amaçlamaktadır (Tosun, 2002: 126). Öyle ki, okullarda istenilen düzeyde öğrenmenin gerçekleşmesi ve eğitimsel hedeflere ulaşılması öğrencilerin ve okul personelinin kendilerini güvende ve özgür hissettikleri bir eğitim ortamının sağlanmasına bağlıdır (Güven ve Dönmez, 2002).

Disiplin toplum, okul veya öğretmenler tarafından önceden belirlenmiş bir kuralı ihlal eden ya da eğitim aktivitelerini engelleyen öğrenciye yönelik öğretmen ya da okul idaresi tarafından gerekli görülen eylemler bütünüdür (Wolfgang, 1999: 5). Eğitim kurumlarında disiplinin amacl; öğrencinin davranış farkındalığını, öz disiplinini, sorumluluk bilincini, otokontrol ve gösterdiği davranış için hesap verme sorumluluğunu geliştirmek, öğrencilerin öğrenmeye odaklı kalmalarını sağlamak, öğrencilerin öz saygılarını geliştirmek, öğrencilere başkalarııın haklarını anlamayı ve onlara saygı göstermeyi öğretmek, öğrencilerin öğrenme sürecinde sorumluluk sahibi olarak bağımsızlık duygusu kazanmalarını ve diğer öğrencilerle işbirliği içinde olmalarını sağlamak, dürüstlük, adil olma ve diğerlerine saygılı olma değerlerini geliştirmek ve rasyonel çatışma çözümleri sağlamaktır (Rogers, 2004: 5).

Birçok durumda disiplin problemi sınıfta ya da okulun başka bir yerinde bir öğrencinin yanlış bir şey yapması anlamına gelir. Açık ya da örtük bir kural ihlal edilmiş ya da öğrenci öğretme-öğrenme sürecini engellemiştir. Çoğu durumda öğrenciye karşı ya da öğrenciyle alınan önlemler öğrencinin daha uygun olana doğru davranışını değiştirme beklentisiyle yürütülür (Mendler, 2007: 55).

\section{Disiplin Yaklaşımları}

Alanyazında çok sayıda disiplin teori ve yöntemleri karşımıza çıkmaktadır. Ancak aşırı derecede önemli olmasına karşın disiplin konusu, nadiren en iyi teoriyi bulmak için araştııılmıştır. Sonuç olarak belirgin bir modelin diğerlerine göre bir üstünlüğü olduğu sonucuna ulaşılamamıştır (Edwards, 2011: v). Bütün çocuklarla bütün durumlar için etkili olabilecek tek bir disiplin uygulamasi ya da yöntemi yoktur. Kesin bir şekilde ödülleri, sonuçları ya da cezaları bütün öğrenciler için tanımlayan herhangi bir program başarısızlığa mahkûmdur. Düzenlemelere rağmen gelişme göstermeyen öğrencilerle ilgili bir sürü örnek mevcuttur (Mendler, 2007: 32). Bu araştırma kapsamında önleyici, düzeltici ve destekleyici disiplin yaklaşımlarına yer verilmiştir.

\section{Önleyici Disiplin:}

Örgütlerin yönetim sürecinde de başvurulan bir yöntem olan önleyici disiplinin öncelikli amacı, kuralların dışına çıkılmasını engellemek ya da bu durumu en aza indirmektir. Bu disiplin anlayışı kural ve düzenlemelerin ihlal edilmemesi için başvurulan bir önceden yönlendirme sürecidir. Burada amaç bireyde bir ceza korkusu oluşturmak değil, yararına inandığı için kurallara uyma bilinci oluşturarak öz disiplini sağlamaktır (Geylan ve Tonus, 2013: 186). En iyi disiplin planının disiplin cezasına gerek bırakmayan, cezayı önlemeye yönelik plan olduğu ileri sürülmektedir (Boynton ve Boynton, 2007: 38). Güçlükler ortaya çıkana kadar beklemektense disiplin problemlerini çözmek en iyisidir. Öğretmenlerin potansiyel problemleri önceden tahmin etme de yetenekli olmaları gerekmektedir (Edwards, 2011: 147). 
Önleyici disiplin öğretmene sınıfla birlikte oluşturulmuş net kurallar ve rutinler, öğrenme görevleri ve davranışlar hakkında net beklenti ve rutinler, iyi planlanmış oda düzeni, materyallere ulaşma, estetik olarak çekici ve olumlu ortam oluşturmak, yeterli kaynaklar, öğretim programını farklı öğrenme yeterliliğine sahip öğrenciler için düzenleme, öğrenciler tekrar eden rahatsız edici ve tehlikeli davranışlar sergilediğinde öğretmenlere destek sağlama konularında kolaylık sağlamaktadır (Rogers, 2004: 4).

\section{Düzeltici disiplin}

Önleyici disiplin çalışmalarına rağmen kural ihlallerinin önüne tümüyle geçmek mümkün olmayabilir. Dolayısıyla kural dışı davranışların düzeltilmesi ve ihlallerin tekrarlanmaması için düzeltici disiplin yaklaşımına başvurulabilir (Geylan ve Tonus, 2013;187). Düzeltici disiplin öğretmenin eylemleri ile ilgilidir. Dikkat dağıtıcı, rahatsız edici, anti-sosyal ya da normal dışı davranışları düzeltmek için öğretmenlerin başvurdukları eylemlerdir. Düzeltici disiplin yaklaşımını benimseyen öğretmenler istenmeyen öğrenci davranışlarına müdahalede; taktiksel olarak bazı davranışları görmezden gelme, açıklayıcı ve sözsüz ipuçları kullanma, sınıf kurallarını hatırlatma ve yeniden ifade etme, basit davranışsal yönlendirme ve uyarılar, dolaylı veya direkt sorgulama, olası çatışmaları etkisiz hale getirme veya yön değiştirme, doğrudan seçimler sunma, öğrencileri gruptan uzaklaştırma, gerekli olduğunda sınıf içi ve dışında mola kullanma gibi yöntemlere başvururlar (Rogers, 2004: 3-4). Düzeltici disiplinde kural ihlalleri durumunda istenmeyen davranışı düzeltmek ve gelecekte aynı davranışın tekrarlanmasını engellemek için başvurulan yöntemlerden biri de cezadır. İstenmeyen davranışı en kısa sürede ve en az maliyetle düzelttiğine ilişkin algı bu yaklaşımın bugüne kadar tüm dünya ülkelerinde geniş bir uygulama alanı bulmasına neden olmuştur. Bu nedenle düzeltici disiplin yaklaşımı klasik disiplin yaklaşımı diye de adlandırımaktadır (Geylan ve Tonus, 2013: 187).

\section{Destekleyici Disiplin}

Öğrenciler kimi durumlarda beklenmedik davranış bozuklukları sergileyebilirler. Bu gibi durumlarda, öğrencilerin kendilerine hâkim olma duygusu kazandırılması ve derslere olan ilgilerin artması için öğrencilerin güdülenmeleri sağlanmalıdır (Esen, 2006: 35). Destekleyici disiplin yaklaşımı düzeltmenin mümkün olduğunca adil bir şekilde yapılmasını sağlar. Disiplin altına alınan öğrencilerle var olan ilişkileri onarma, yeniden kurma, düzenlemeyi içerir. Destekleyici disiplin yaklaşımını benimseyen öğretmenler; bilinçli olarak bir saygı iklimi oluşturma ve geliştirme, olumlu bir sınıf atmosferi oluşturma, kişiler arası yüksek gerilim yatıştığında istenmeyen davranış sergileyen öğrencilerle iletişime geçme, mümkün olan her yerde öğrencileri güdüleme, motive etme, öğrenciyle bireysel davranışlarla ilgili anlaşma sağlama ve disiplin problemlerinin çözümünde ekip yaklaşımı gibi uygulamalara başvurabilir (Rogers, 2004: 3-4).

\section{Disiplinin problemlerinde rol oynayan etkenler}

Eğitim sistemimizle öğrencilere kazandırılmak istenen hedef davranışların öğretme-öğrenme süreçleriyle kazandııılığı okulların da kuşkusuz çeşitli iç ve dış etmenler açısından kendine özgü yönleri vardır. Bu açıdan okullarda yaşanan disiplin problemleri, bunların nedenleri ve çözümüne ilişkin başvurulan uygulamalar okulun bulunduğu çevre, öğretmenler, öğrenciler, sınıf vb. gibi bir takım etmenlerden dolayı farklııık göstermektedir.

Okul ortamında istenilen düzeyde bir disiplinin varlığını sağlamak için garantili bir yol yoktur. Fakat pozitif bir eğitim ortamı oluşturmak, etkili ve başarılı bir okul ortamı yaratmak için (Ada ve Çetin, 2006: 102) birtakım etkenlerin göz önünde bulundurulması gerekir.

\section{Öğrenci kaynaklı etkenler}

Her okulda toplumun ve okulun onayladığı davranışları sergileyen öğrencilerin yanı sıra bir takım istenmeyen davranışlar sergileyen öğrenciler de çıkabilmektedir. Bu durum, diğer öğrencileri de olumsuz bir şekilde etkilemektedir. Öğretmenler ve okul yöneticilerinin istenmeyen davranışları 
büyümeden pozitif disiplin anlayışılla yaklaşarak öğrenci ile birlikte çözmeleri gerekmektedir (Ada ve Çetin, 2006: 86).

Öğrenciler arasında sosyal, ekonomik ve psikolojik yönlerden çok çeşitli farklılıklar vardır. Ailenin gelir ve eğitim düzeyi, çocuk sayısı, değerleri, inançları, ana babanın mesleği, çocuğa ve okula karşı tutumları, eğitime verdikleri değer, çocuğun cinsiyeti, yetenekleri, fiziksel özellikleri, yaşı gibi birçok yönden öğrenciler birbirlerinden farklıdırlar. Bütün bu farklı özellikleriyle sınıfa gelen öğrencilerin davranışlarında, olaylara bakış açlarında, kendilerini ifade etmede farklıııkların olması doğaldır (Şişman ve Turan, 2008: 19).

Her sınıfta \%60 -70 oranında öğretmenleri ile işbirliği içerisinde çalışılabilir bir sınıf ortamı oluşturmaya ve bunu sürdürmeye istekli bir öğrenci grubu vardır. Öğretmenin etkili öğretimi, olumlu ve saygıya dayalı liderliği ile bu öğrenci grubu işbirliği içerisinde olmaya devam edecektir. Ancak öğretmenin öğretim ve yönetim sürecinde bilinç, kendine güven ve pozitif bir yapının yoksunluğu bu grubun iyi niyetinin azalmasına neden olacaktır (Rogers, 2004: 57).

\section{Öğretmen kaynaklı etkenler}

Öğretmen sınıf kültürü oluşturulmasında önemli bir öğedir. Davranış bilimleri öğrencilerin öğretmenin tutum ve davranışlarından etkilendiğini göstermektedir. Çoğu zaman öğrenci öğretmenin ne söylediğinden çok ne yaptığı ve nasıl yaptığıyla ilgilenir. Öğretmen sınıf iklimini öğrenciler için uygun hale getirmeli ve bu iklimi sürdürmek için ise öğrencilerin kendilerini güvende hissettikleri bir ortam oluşturmalıdır. Öğretmenler sınıf ortamında, liderlik, öğreticilik temsilcilik, arabuluculuk, yargıçlık, rehberlik, danışmanlık, ana-babalık gibi birçok role bürünürler (Şişman ve Turan, 2008: 18).

Öğretmenler eğitim-öğretim etkinliklerini düzenlemenin yanı sıra disiplini de sağlamaktadır. Bu süreçte kimi zaman öğretmenden kaynaklanan disiplin problemleri de ortaya çıkabilmektedir (Ada ve Çetin, 2006: 82). En iyi öğretmenler bile disiplin problemleri ile karşılaşacaktır. Disiplin sınıf yönetiminin kaçınılmaz bir parçasıdır (Tauber, 1999; 15).

Her öğretmenin bir yöntemi vardır (Kohn, 2006: 2). Sınıf disiplininin öğrencilerin ahlaki gelişiminde kaçınılmaz bir etkisi vardır (Butchart ve McEwan, 1997: 11). Öğretmenin sınıf yönetimi konusundaki yeterliliği öğrenci davranışlarını yönetmede ve disiplini sağlamada kolaylık sağlayacaktır (Şişman ve Turan, 2008: 43).

Öğretmenler sınıfta olup biten her şeyi her zaman görmek ve bilmek zorundadır. Öğretmenin ilk işi sınıftaki düzensizlikleri azaltmak, yıkıcı davranışları durdurmak ve ortadan kaldırmaktır. Öğretmenin sınıfta düzensizliklerle başa çıkamadığını fark eden öğrenciler, öğretmenin çabalarını etkisizi kılıcı davranış gösterme çabalarını arttırabilirler (Celep, 2000: 22).

\section{Okul yönetiminden kaynaklanan etkenler}

Davranış oluşturma ve değiştirme amaçlı etkinlikler bütünü olarak nitelendirilen eğitim süreci okullar yoluyla yürütülmektedir. Okullar öğrencileri dış çevrenin güçlüklerinden korumak ve onlar için yaşamı kolaylaştırmak, dış çevrede kolay rastlanabilecek istenmeyen nitelikteki davranışları okulun içine sokmayarak öğrenci davranışlarını düzenlemek ve böylece dış çevrede yaşama ilişkin farklııkların kendi sınırları içerisinde yaşanmasına izin vermeyerek toplumsal yaşamda olmayan dengeyi aynı forma, sıra, öğretmen vb. unsurlar ile kendi sınırları içerisinde kurması gereken kurumlardır (Başar, 1999: 11-12).

Eğitsel liderler olarak okul yöneticileri okulun kültür, değer ve inançları ile uyumlu, okul çapında disiplini sağlayacak bir öğrenme ortamı oluşturmak için gayret göstermelidir. Kurumsal disiplini etkileyen faktörler; öğrenci performans, tutum ve davranışının yönetimi ve alınan önlemlerdir (Deshmukh, 2015: 211). 
Okul çapında disiplin politikası, her öğretmenin sınıf içi davranış standartları geliştirmesi açısından genel ilkeleri oluşturabilir. İdeal olarak, bu ilkeler bir öğretmenin standartlarının diğer öğretmenlerinkiyle çatışmasını önlemek için yeterli yönlendirme sağlarken öğretmenlere bir otonomi verecek esnekliktedir. Okul çapındaki disiplin politikası bireysel olarak öğretmenin sınıf standartlarının uygulanmasını destekleyici olabilir (Cangelosi, 2016: 151).Insanların birbirine sevgi ve saygı gösterdiği ortak amaçlar çerçevesinde görev ve sorumluluk duygusuna sahip, işbirliğinin güçlü olduğu okullarda davranışla ilgili sorunlara daha az rastlanmaktadır (Şişman ve Turan, 2008: 43).

\section{Öğretim Programından kaynaklanan etkenler}

Disiplin ve öğretim programı birbirinin ayrılmaz bir parçası olarak kabul edilmektedir. Birbirinden net bir şekilde bağımsız gibi görünseler de, amaçlar ve süreçlerde bu ikisinin bir bütün olduğu ve birbirini tamamladığı görülmektedir. Olası disiplin problemleri bütünleşik öğretimsel süreçlerin uygulanmasıyla önlenebilir. Yani herhangi bir disiplin problemi öğretmen tarafından öğretimsel içeriğe dahil edilebilir (Edwards, 2011: vii).

Öğretmenin derse ve konuya uygun olmayan müfredat ve öğretim stratejilerini izlemesi öğrencilerde istenmeyen davranışların oluşmasına neden olur. Diğer taraftan derste kullanılan yöntem doğru olsa bile öğrencinin bazı yanlış davranışları öğretmenin yetersizliğinden ya da öğrencilerin çeşitli gereksinimleri karşılanmamasından kaynaklanabilir. Öğretmen, derste kullanacağı öğretim stratejisini belirlerken öğrenci grubunun büyüklüğü, öğrencilerin özellikleri, kaynaklardan yararlanma imkânı ve ders için ayrılan zaman gibi değişkenleri dikkate alması gereklidir (Şişman ve Turan, 2008: 49).

Öğretmenler öğretim programı ve amaçları esas alarak yıllık ünite ve günlük planlarını oluşturmalı, kaynak kitaplarını belirleyip, araç-gereç ve yöntemleri öğrenci özelliklerini göz önünde bulundurarak belirlemelidir (Başar, 2014: 7). Öğretmenin öğretim tarzını benimsemeyen öğrenci zamanla ders içeriğinin kendi yeteneklerinin sınırlarını aştığını düşünerek öğrenmeyi reddetme, kendini yetersiz görme ve derste bulunma gerekliliğini sorgulama eğilimi gösterebilir (Şişman ve Turan, 2008: 49).

\section{Öğretim Ortamının Düzenlenmesi ile ilgili etkenler}

Araştırmalar sınıfların uygun şekilde fiziksel düzenlenmesinin öğrencilerin öğrenme derecesini arttırdığını saptamıştır (Celep, 2000: 23). Sınıflar sadece öğrencilerin öğrenim gördükleri yerler değil aynı zamanda onlar için birer yaşama alanıdır. Sınıf eğitimsel süreçlerin temel birimidir. Bu yüzden öğrencilerin özelliklerine uygun şekilde düzenlenmelidir (Şişman ve Turan, 2008: 31). Sınıftaki her alan öğrenci için öğrenme uyaranı niteliği taşımalıdır. Sınıfın fiziksel yapısının düzensiz, havasız, gürültülü, sınıf dışı olumsuz uyaranlara açık olması öğrenmeyi olumsuz yönde etkiler (Celep, 2000: 18).

Sınıfın büyüklüğü, ışıklandııılması ve öğrencilerin öğrenim gördükleri ortamların sıcaklığı öğrenci başarı üzerinde etkilidir. Ayrıca sınıf içi renkleri belirlemede öğrenci özellikleri göz önünde bulundurulmalı ve sınıfta mümkün olduğunca güneş ışığından yararlanılmalıdır (Şişman ve Turan 2008: 29-33; Toprakcı, 2017, 92).

\section{Aile kaynaklı etkenler}

Okullarda yaşanan disiplin problemlerine neden olan etmenler sadece okul içindeki durumlarla da sınırlı değildir. İnsan davranışları onun parçası olduğu doğanın, çevrenin bilinmesi halinde daha iyi anlaşılır (Türnüklü, 2006: 11). İnsanın içinde doğup büyüdüğü kişiliğinin şekillendiği ailenin kişinin yaşamındaki yeri çok önemlidir. Çocuğun yaşamının ilk yıllarında kazanmış olduğu deneyim aile içinde oluşur. Okulda karşılaşılan disiplin sorunlarının çoğunun temelinde çocuğun ailede kazanmış olduğu kişilik özellikleri ve alışkanlıklar yatmaktadır (Ada ve Çetin, 2006: 91; Toprakcı, 2017, 55). 
Bireyin sosyalleşmesinde rol oynayan aile onun sınıf içi ve sınıf dışı davranışlarını etkileyen faktörlerden biridir. Farklı sosyal tabaka ve çevrelerden gelen öğrenciler çevreden edindiklerini bütün özelliklerini sınıfa taşır (Şişman ve Turan, 2008: 83; Toprakcı, 2017, 53).

Çocuklar velileri sıklıkla evde bulunmadıklarında ihtiyaçlarını karşılamada zorlanabilirler. Bu durum onların yıkıcı etkileri olabilecek hatta yasa dışı bir takım grup ve etkinliklerin içine girmelerine neden olabilir. Çete eylemleri ailenin ihmal veya yokluğunun bir sonucudur. Bunların dışında; yoksulluk, boşanma, ev içindeki çatışmalar, fiziksel ve zihinsel şiddet çocukların okulda uygun şekilde eğitim alma yeteneğini olumsuz bir şekilde etkileyebilir (Edwards, 2011: 42).

\section{Araştırmanın Amacı}

Günümüz dünyasında okullarda yaşanan disiplin problemleri, okullarda gittikçe büyüyen bir sorun olarak karşımıza çıkmaktadır. Bu sorunların çözümünde yönetmeliklerde belirlenen esaslara göre yaptırımlar uygulanmakla beraber, istenmeyen davranışın niteliği, davranışın gerektirdiği cezanın uygunluğu ve etkisi, okullarda yaşanan disiplin sorunlarının ele alınış şekli konusundaki farklılıkların tartışılması ve ortaya konulması önem arz etmektedir. Okullarda karşılaşılan istenmeyen davranışların niteliği, türü, şiddeti ve bunların nedenleri okuldan okula farklılık gösterirken, alınan önlemler noktasında yönetmelik ve yaptırımlara başvurma konusunda farklı yaklaşımlar sergilemesi muhtemeldir ve ayrıca bir gerekliliktir. Bu çalışmada aşağıdaki sorulara yanıt aranmıştır:

1-Okullarda yaşanan disiplin problemlerinin çözümünde okul yöneticileri hangi tur yaklaşımları tercih etmektedir? nelerdir?

2-Okul yöneticilerinin disiplin problemlerinin çözümüne yönelik özgün uygulamaları

\section{YÖNTEM}

Bu araştırmada durum çalışması desenlerinden bütüncül çoklu durum desenine başvurulmuştur. Bu araştırma deseninde her bir durum kendi içinde bütüncül olarak ele alınır ve daha sonra birbirleriyle karşılaştırılır (Yıldırım ve Şimşek, 2006: 291-292).

\section{Çalışma Grubu}

Araştırmada, nitel araştırmalarda yaygın olarak kullanılan ve zengin bilgiye sahip olduğu düşünülen durumların derinlemesine çalışılmasına olanak veren amaçlı örnekleme yöntemlerinden maksimum çeşitlilik örneklemesi tercih edilmiştir. Maksimum çeşitliliğe dayalı örneklem oluşturmada amaç, bu çeşitlilikle genelleme yapmaktan ziyade, çeşitlilik gösteren durumlar hakkında herhangi bir ortak olgunun olup olmadığını bulmaya çalışmak ve aynı ölçüde de farklılıkların var olup olmadığını bulmaktır (Yıldırım ve Şimşek, 2006: 107-109). Bu amaçla araştırma kapsamına alınan sosyo-ekonomik düzeyi yüksek, düşük ve orta düzeyde olan ortaokullar, Fen ve Sosyal Bilimler liseleri, Anadolu Liseleri ve Mesleki ve Teknik Liselerde görev yapan yöneticiler bu araştırmanın katılımcı grubunu oluşturmaktadır. Bilgi kaynağı olarak yöneticilerin seçilmesi, okullarda disiplininin sağlanması sürecinin yürütücüsü konumunda olmalarından kaynaklanmaktadır. Yönetici katılımcılar, belirlenen 25 okulun müdür $(n=15)$ veya müdür yardımcılarından $(n=10)$ oluşmaktadır. Katılımcılara ait bilgiler aşağıda Tablo 1 'de verilmiştir; tablo ve metinlerin okunmasını kolaylaştırması amacıyla katılımcılar, Y1, Y2 (Yönetici1, Yönetici2) şeklinde kodlanmıştır. 
Tablo 1. Araştırmaya Katılan Yöneticilere Illişkin Bilgiler

\begin{tabular}{llcc}
\hline Değişken & Seçenekler & f & \% \\
\hline Cinsiyet & Erkek & 20 & 80 \\
& Kadin & 5 & 20 \\
\hline Gorevi & Müdür & 15 & 60 \\
& Müdür Yardimcisi & 10 & 40 \\
\hline Egitim Duzeyi & Lisans & 20 & 80 \\
& Yüksek Lisans & 5 & 20 \\
\hline Yoneticilikteki Kidemi & $1-5$ Yil & 6 & 24 \\
& 5-10 Yil & 11 & 44 \\
& 10 yil ve üstü & 8 & 32 \\
\hline Okul Turu & Ortaokul & 11 & 44 \\
& Lise & 14 & 56 \\
\hline \multirow{3}{*}{$\begin{array}{l}\text { Okulun bulundugu cevrenin sosyo- } \\
\text { ekonomik duzeyi }\end{array}$} & Düsük SED & 3 & 12 \\
\hline Lise Turu & Orta SED & 5 & 20 \\
& Yüksek SED & 3 & 12 \\
\hline
\end{tabular}

\section{Verilerin Toplanması}

Araştırmanın verileri, yarı yapılandırılmış görüşme formu ile görüşme tekniği kullanılarak toplanmıştır. Araştırmada görüşme yapılacak yöneticilerle önceden görüşülerek konuyla ilgili bilgiler kendilerine iletilmiştir. Görüşmeler yöneticilerin kendi ofislerinde gerçekleştirilmiş ve görüşmelerde ses kayıt cihazı kullanılmıştır. Ancak katılımcılardan bazılarının talebi ile görüşme sırasında kayıt cihazı kullanılmamış ve araştırmacı anlatılanları bire bir not tutmuştur.

\section{Verilerin Analizi ve Çözümlenmesi}

$\mathrm{Bu}$ araştırmada elde edilen veriler, içerik analizi yoluyla analiz edilmiş ve yorumlanmıştır. Iç̧erik analizi toplanan verileri açıklayabilecek kavram ve ilişkilere ulaşmak amacıyla yapılan (Yıldırım ve şimşek, 2006: 227) belirli kurallara dayalı kodlamalarla bir metnin bazı sözcüklerinin daha küçük içerik kategorileri ile özetlendiği sistematik bir tekniktir (Büyüköztürk, Çakmak, Akgün, Karadeniz ve Demirel, 2010: 269-273).

Bu çerçevede, öncelikle metne dönüştürülen görüşme kayıtlarının tamamı bilgisayar ortamına aktarılmış, yazım ve dilbilgisi açısından kontrol edilmiş ve uygun tanımlamalara ve kodlamalara hazır hale getirilmiştir. Veriler önce belirlenen temalara göre kodlanmış, sınıflandırılmış, araştırılan duruma ilişkin olgular açığa çıkarılmaya çalışılmıştır. Bulgular, oluşturulan temalar tablolaştııılarak ve katılımcılardan doğrudan alıntılar yardımıyla sunulmuştur.

\section{Geçerlik ve Güvenirlik Çalışmaları}

Araştırmanın geçerlik ve güvenirliğini sağlamak amacıyla; farklı özelliklere sahip (cinsiyet, çalışılan okul türü, meslekteki kıdem, eğitim düzeyi vb.) katılımcılar araştırmanın çalışma grubuna dâhil edilerek çalışma grubunun çeşitliliği sağlanmıştır. Görüşme formunun hazırlanma sürecine Inönü Üniversitesi Eğitim Bilimleri Bölümünden iki öğretim üyesinden uzman görüşü alınmıştır. Veri toplama süreci içinde genel hatlarıly belirlenen kavramlar ve temalar için toplanan verilerin bir doygunluk sağladığı tespit edildikten sonra veri toplama işlemi sonlandırılmıştır. Böylece veri toplama süreçlerine uygun ve yeterli katılım sağlanmaya çalışılış̧ı. Görüşmenin sonunda elde edilen bilgiler katılımcılara sunulmuş ve oluşabilecek eksiklik ve yanlışlıklara karşı teyit ettirilmiştir. "Bulgular" bölümünde ham verilerin bir kısmı ortaya çıkan temalara göre yorum katmadan ve verinin doğasına mümkün olduğunca sadık kalarak aktarılmıştır. Böylece ayrıntııı betimleme yapılmaya çalışılmıştır.

Nitel araştırmalarda elde edilen ölçümlerin anlamlı olması kabul edilebilir bir güvenirlik düzeyinin sağlanmasına bağlıdır (Neuendorf, 2002: 12). Elde edilen sonuçların güvenilir olabilmesi için farklı kişiler tarafından yapılan kodlamaların ve temaların tutarlıık göstermesi gerekir. Sınıflandırma işleminin birden fazla kişi tarafından yapııması araştırmanın güvenilirliğinin 
değerlendirilmesine olanak sağlar (Weber, 1990). Verilerin analizinde oluşturulan kodlar ve temalar İnönü Üniversitesi Eğitim Bilimleri Bölümünden bir öğretim üyesi tarafından kontrol edilmiş ve kodların ikinci bir kişi tarafından da benzer şekilde temalandırılabileceği teyit edilmiştir. Bu bağlamda, iç güvenirliğin sağlanması amacıyla Miles ve Huberman (1994) tarafından önerilen formül (güvenirlik = görüş birliği/görüş birliği + görüş ayrılığı) kullanılarak iki araştırmacı arasındaki uyuşum oranı 0.83 olarak bulunmuştur. Miles ve Huberman'a (1994) göre, çalışmanın güvenilirliğinin kabul edilebilir düzeyde olması için, araştırmacılar arasındaki uyuşum oranının \%70 ve üzeri olması gerekmektedir. Buna göre sonuçların kabul edilebilir sınırlar dahilinde olduğu söylenebilir.

\section{BULGULAR}

Bu araştırma kapsamına alınan okullarda okul yöneticilerine okullarında disiplini sağlama adına başvurdukları uygulamalar sorulmuş ve elde edilen bulguların frekans ve yüzde değerleri hesaplanmıştır. Tablo 2'de bu uygulamalar ile ilgili olarak okul yöneticilerinin görüşlerinin frekans ve yüzdeleri sunulmaktadır. Bu tabloya göre, disiplin sorunları ile başa çıkmada kullandıkları yaklaşımlar konusunda okullarda başvurulan uygulamalara ilişkin okul yöneticilerinin görüşlerinin Önleyici, Destekleyici ve Düzeltici Disiplin Yaklaşımları olmak üzere üç tema altında toplandığı görülmektedir.

\section{Önleyici Disiplin Yaklaşımı}

Araştırmada "Önleyici Disiplin Yaklaşımı" temasına uygun görüşlerin ağırlıkta olduğu görülmektedir. Okul yöneticileri disiplini sağlamak için aldıkları önlemlerin sorunun ortaya çıkmasını engellemede etkili olduğunu belirtmişlerdir. "Önleyici Disiplin Yaklaşımı" teması altında okul veli ilişkisini güçlendirmenin, sosyal ve sportif etkinlikler düzenleyerek öğrencilerin katııımını teşvik etmenin, sorunlar ortaya çıkmadan önce önlem almanın, ayın sınıfı, ayın öğrencisi uygulamalarıyla öğrencileri motive etmenin, olumlu davranış sergileyen örnek öğrencileri ödüllendirmenin okulda disiplin problemlerine ilişkin kullandıkları başlıca çözüm yaklaşımları olduğunu belirtmişlerdir.

Öğrenci davranışlarıyla ilgili olumsuz durum oluşmasını önlemek için yöneticilerin en sık başvurduğu uygulama okul veli ilişkisini güçlendirmektir. Öyle ki katılımcıların \%84'ü $(n=21)$ okul veli ilişkisinin güçlü olmasının sorunların ortaya çıkmasını engellemede etkili olacağı yönünde görüş bildirmiştir. Bu konudaki yönetici görüşlerinden bazılar şunlardır:

Okul toplu yaşanan yer. Herkesin yaşam hakkı var. Bunları telkin ediyor, saygının vazgeçilmez bir değer olduğunu vermeye çalışıoruz. Sınıfta rehber öğretmen ve velilere ögrencilere toplantı ve seminerler düzenliyoruz. Ailelerin de süreçlere dahil olması için iletişim kanallarını sürekli açık tutuyoruz.(Y10)

Okulda disiplin sorunlarına neden olan öğrencilerin velilerine anket yaparı. Kendi fotoğraflarını görebilmeleri ve biz görelim diye (Y11)

Veli ve öğrencilerle olumlu ve sağlkkı iletişim kurduğumuzu düşünüyoruz. Yani yönetici ve ögretmenlerle ögrenci ve veliler arasında aşılmaz duvarlar yok. Velilerimiz duyarlı (Y12)

Bir arada zamanın geçirildiği bir ortam olan okullarda iletişimde çatışmaların olmasını önlemek için öğrencilerin kendi yeteneklerini keşfetmeleri ve sergilemeleri için bir takım kültürel, sosyal ve spor etkinliklere öğrencilerin katıımını teşvik ederek enerjilerini bu alanlarda atmalarını sağlamak üzere yöneticilerin \%56'sı $(n=14)$ bu tür etkinliklerin düzenlenmesi ve katılımı konusunda çaba gösterdiklerini ifade etmişlerdir. Bu konuda yöneticilerin görüşleri aşağıda verilmiştir:

Sosyal etkinliklere ögrrencileri yönlendiriyor, iyi davranışları takdir ederek törenlerde bunları dile getiriyoruz. Okulumuzda kültür sanat ve sportif etkinliklerde çok ödüller alınd.. (Y19)

Okulumuzda sosyal etkinlikler muazzam. Bir sinerji var. Kahvaltılar, piknikler kaynaşmayı sağlıyor ve aile ve öğretmenin içiçe olmasını sağlıyor. Temizlik kolu ayın temiz sınıfı ödülünü veriyor. (Y10) 
Sosyal faaliyetleri cazip hale getirdik. Öğrencilerimiz hemen her branşta,oriyentiringten tutun atıcllı̆a kadar, okul düzeyinde çeşitli yarışmalara katlıyor. Çeşitli illerde dereceler aldılar. Müzik alanında güzel çalışmalar oldu, bir koromuz var. Öğrencilerimizi ilgi yeteneğine göre sanatsal sportif ve bilimsel faaliyetlere yönlendirdik. Mezuniyet gecesi, sanatsal, tarihi geceler, turnuvalar, sportif etkinlikler düzenledik. Böylece, çocuk kendini okula ait hissediyor, gelmek istiyor. Yardım toplama kampanyaları, huzurevi ziyaretleri düzenledik. Öğrencilerimiz sosyal, biz onların alanlarını daraltmak değil önlerini açmak istiyoruz. Bu sayede disiplin olayı da azaldı (Y13)

Tablo 2. Okul disiplinini sağlamada yöneticiler $(n=25)$ tarafından başvurulan uygulamalar

\begin{tabular}{|c|c|c|c|c|}
\hline $\begin{array}{l}\text { Tem } \\
\text { alar }\end{array}$ & Temalara ilişkin boyutlar & Katılımcılar & $\mathbf{f}$ & $\%$ \\
\hline \multirow{19}{*}{ 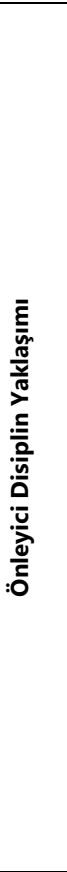 } & Okul veli ilişkisini güçlendirme & \begin{tabular}{|l|}
$\mathrm{Y} 1, \mathrm{Y} 2, \mathrm{Y} 3, \mathrm{Y} 4, \mathrm{Y} 5, \mathrm{Y} 6, \mathrm{Y} 7, \mathrm{Y} 8, \mathrm{Y} 10, \mathrm{Y} 11$ \\
$\mathrm{Y} 12, \mathrm{Y} 13, \mathrm{Y} 15, \mathrm{Y} 16, \mathrm{Y} 17, \mathrm{Y} 18, \mathrm{Y} 19, \mathrm{Y} 20, \mathrm{Y} 21, \mathrm{Y} 24, \mathrm{Y} 25$
\end{tabular} & 21 & 84 \\
\hline & $\begin{array}{l}\text { Sosyal ve sportif etkinlikler düzenleyerek öğrencilerin } \\
\text { katııımını teşvik etme }\end{array}$ & $\mathrm{Y} 2, \mathrm{Y} 3, \mathrm{Y} 5, \mathrm{Y} 10, \mathrm{Y} 13, \mathrm{Y} 14, \mathrm{Y} 16, \mathrm{Y} 17, \mathrm{Y} 19, \mathrm{Y} 20, \mathrm{Y} 22, \mathrm{Y} 23, \mathrm{Y} 24, \mathrm{Y} 25$ & 14 & 56 \\
\hline & Sorunlar ortaya çıkmadan önce önlem alma & $\mathrm{Y1}, \mathrm{Y4}, \mathrm{Y5}, \mathrm{Y} 6, \mathrm{Y} 10, \mathrm{Y} 11, \mathrm{Y15}, \mathrm{Y16}, \mathrm{Y17}, \mathrm{Y} 20, \mathrm{Y} 22, \mathrm{Y} 25$ & 12 & 48 \\
\hline & $\begin{array}{l}\text { Ayın sınıfı, ayın öğrencisi uygulamalarıyla öğrencileri } \\
\text { motive etme }\end{array}$ & $\mathrm{Y4}, \mathrm{Y} 7, \mathrm{Y} 8, \mathrm{Y9}, \mathrm{Y} 10, \mathrm{Y11}, \mathrm{Y} 19, \mathrm{Y} 21, \mathrm{Y} 23$ & 9 & 36 \\
\hline & $\begin{array}{l}\text { Olumlu davranış sergileyen örnek öğrencileri } \\
\text { ödüllendirme }\end{array}$ & Y3,Y4,Y7,Y9,Y11,Y12,Y15,Y18, 22 & 9 & 36 \\
\hline & Özel güvenlik görevlisinin olması & Y2,Y8,Y10,Y12,Y13,Y20,Y22, Y24, & 8 & 32 \\
\hline & $\begin{array}{l}\text { Maddi durumu iyi olmayan öğrencilere yemek, yol, } \\
\text { giyim yardımı }\end{array}$ & Y3, Y7, Y9,Y11, Y14, Y19,Y20, Y25 & 8 & 32 \\
\hline & Akademik başarısı olan öğrencileri ödüllendirme & $\mathrm{Y} 6, \mathrm{Y} 13, \mathrm{Y} 14, \mathrm{Y} 18, \mathrm{Y} 21, \mathrm{Y} 24, \mathrm{Y} 25$ & 7 & 28 \\
\hline & Öğrencilerin okuldaki kuralların farkında olması & $\mathrm{Y} 3, \mathrm{Y} 4, \mathrm{Y} 13, \mathrm{Y} 17, \mathrm{Y} 22, \mathrm{Y} 23$ & 6 & 24 \\
\hline & Fiziki mekanları iyileştirme & Y7, Y11, Y19, Y24 & 4 & 20 \\
\hline & $\begin{array}{l}\text { Kültür, sanat ve spor etkinliklerinde başarılı öğrencileri } \\
\text { ödüllendirme }\end{array}$ & Y15, Y18, Y20, Y24, Y25 & 5 & 20 \\
\hline & Güçlü bir okul kültürünün varlığı & Y4, Y8, Y13, Y21, & 4 & 16 \\
\hline & Öğle arasında dışarı çıkarmama & Y3, Y16, Y22 & 3 & 12 \\
\hline & Her tür güvenlik tedbirlerinin alınması & Y17, Y20, Y25 & 3 & 12 \\
\hline & Cep telefonu getirmeye izin verme & Y13, Y16, Y21, & 3 & 12 \\
\hline & Verdiği görevi takip etme & Y2, Y21 & 2 & 8 \\
\hline & Giriş-çıkışların kontrollü olması & Y6, Y17 & 2 & 8 \\
\hline & Konferans ve spor salonunun aktif kullanımı & $\mathrm{Y} 1, \mathrm{Y} 8$ & 2 & 8 \\
\hline & Ev ziyaretleri & $\mathrm{Y} 14, \mathrm{Y} 16$ & 2 & 8 \\
\hline \multirow{10}{*}{ 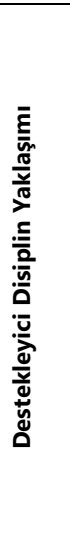 } & $\begin{array}{l}\text { Öğretmenlerin problem çözümünde işbirliği ve katkı } \\
\text { sağlaması }\end{array}$ & $\begin{array}{l}\mathrm{Y} 1, \mathrm{Y} 2, \mathrm{Y3}, \mathrm{Y4}, \mathrm{Y} 5, \mathrm{Y} 6, \mathrm{Y} 7, \mathrm{Y} 8, \mathrm{Y} 9, \mathrm{Y} 10, \mathrm{Y} 11, \mathrm{Y} 13, \mathrm{Y} 14, \mathrm{Y} 15, \\
\mathrm{Y} 16, \mathrm{Y} 17, \mathrm{Y} 18, \mathrm{Y} 19, \mathrm{Y} 22, \mathrm{Y} 23, \mathrm{Y} 24, \mathrm{Y} 25\end{array}$ & 22 & 88 \\
\hline & Rehberlik Servisinden Destek alma & $\begin{array}{l}\mathrm{Y} 1, \mathrm{Y} 2, \mathrm{Y} 3, \mathrm{Y} 5, \mathrm{Y} 6, \mathrm{Y} 7, \mathrm{Y} 8, \mathrm{Y} 10, \mathrm{Y} 11, \mathrm{Y} 13 \\
\mathrm{Y14}, \mathrm{Y} 15, \mathrm{Y} 17, \mathrm{Y} 18, \mathrm{Y} 20, \mathrm{Y} 21, \mathrm{Y} 23, \mathrm{Y} 24 \\
\end{array}$ & 18 & 72 \\
\hline & Sınıf rehber öğretmeninin çalışmaları & $\mathrm{Y1}, \mathrm{Y} 2, \mathrm{Y} 5, \mathrm{Y} 7, \mathrm{Y} 8, \mathrm{Y} 10, \mathrm{Y} 14, \mathrm{Y} 15, \mathrm{Y} 17, \mathrm{Y} 20, \mathrm{Y} 21, \mathrm{Y} 11, \mathrm{Y} 25$ & 13 & 52 \\
\hline & Açık, eşit ve şeffaf davranma & Y5, Y12, Y18, Y19, Y22, Y25 & 6 & 24 \\
\hline & $\begin{array}{l}\text { Olumsuz davranış sergileyen öğrencilerin } \\
\text { gözlemlenmesi için gayri-resmi kayıt altına alınması }\end{array}$ & Y3, Y7, Y10, Y14, Y18 & 5 & 20 \\
\hline & Olaylara yerinde ve zamanında müdahale & $\mathrm{Y} 11, \mathrm{Y} 14, \mathrm{Y} 17, \mathrm{Y} 18, \mathrm{Y} 21$ & 5 & 20 \\
\hline & Öğretmeni karar alma sürecine katma & $\mathrm{Y} 1, \mathrm{Y} 2, \mathrm{Y} 13, \mathrm{Y} 15, \mathrm{Y} 22$ & 5 & 20 \\
\hline & $\begin{array}{l}\text { Sınıf sınıf dolaşarak öğrencileri yaşanan sorunlarla ilgili } \\
\text { uyarma }\end{array}$ & Y9, Y21, & 2 & 8 \\
\hline & Öğrencilerle değer verdiğini gösterme & $\mathrm{Y} 12, \mathrm{Y} 18$ & 2 & 8 \\
\hline & Uygulama iyi gitmiyorsa vazgeçme & Y13 & 1 & 4 \\
\hline \multirow{9}{*}{ 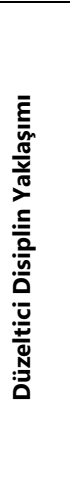 } & Olumsuz davranışla ilgili veliyi bilgilendirme & $\begin{array}{l}\text { Y1, Y2, Y3, Y5, Y6, Y7, Y8, Y9, Y10, Y11, Y12, Y13,Y14, } \\
\text { Y15, Y17, Y18, Y19, Y21, Y22, Y24, Y25 } \\
\end{array}$ & 21 & 84 \\
\hline & Disiplin Cezası Verme & $\begin{array}{l}\text { Y4,Y7,Y9, Y10,Y12,Y13,Y15,Y16, } \\
\text { Y17,Y18,Y19,Y20,Y21,Y22,Y23, Y24, }\end{array}$ & 16 & 64 \\
\hline & Disiplin ile ilgili Kurulu Toplama & $\begin{array}{l}\text { Y1, Y9, Y12, Y15, Y16, Y17,Y18,Y19, Y20, Y21, Y22,Y23, } \\
\text { Y24, Y25 }\end{array}$ & 14 & 56 \\
\hline & $\begin{array}{l}\text { Yapılan olumsuz davranışla ilgili öğrencilerle konuşup } \\
\text { sorunu anlamaya çalışmak }\end{array}$ & Y1, Y2,Y7, Y12, Y13, Y15,Y16,Y17,Y18,Y20,Y22, Y23, & 12 & 48 \\
\hline & Cezaya en son yöntem olarak başvurma & $\mathrm{Y} 1, \mathrm{Y} 2, \mathrm{Y} 4, \mathrm{Y} 5, \mathrm{Y} 10, \mathrm{Y} 12, \mathrm{Y} 14, \mathrm{Y} 15, \mathrm{Y} 17, \mathrm{Y} 22, \mathrm{Y} 23, \mathrm{Y} 25$ & 12 & 48 \\
\hline & $\begin{array}{l}\text { Öğrencileri yapmış olduğu davranıştan dolayı sözlü } \\
\text { olarak uyarma }\end{array}$ & Y2, Y3, Y4, Y11, Y13, Y14,Y16, Y17, Y20, Y21, Y24 & 11 & 44 \\
\hline & Emniyet güçlerinden destek alınması & $\mathrm{Y} 1, \mathrm{Y} 6, \mathrm{Y} 7, \mathrm{Y} 12, \mathrm{Y} 14, \mathrm{Y} 19, \mathrm{Y} 22, \mathrm{Y} 23$ & 8 & 32 \\
\hline & Aralarında çatışma olan öğrencileri uzlaştırma & Y7, Y11, Y19 & 3 & 16 \\
\hline & Azarlama & Y4, Y9 & 2 & 8 \\
\hline
\end{tabular}




\section{Destekleyici Disiplin Yaklaşımı}

"Destekleyici Disiplin Yaklaşımı" teması altında öğretmenlerin problem çözümünde işbirliği ve katkı sağlamasının, rehberlik servisinden destek almanın, olumsuz davranış sergileyen öğrencilerin gözlemlenmesi için gayri-resmi kayıt altına alınmasının, açık, eşit ve şeffaf davranmanın, olaylara yerinde ve zamanında müdahalenin, öğretmeni karar alma sürecine katmanın, Sınıf sınıf dolaşarak öğrencileri yaşanan sorunlarla ilgili uyarmanın,öğrencilere değer verdiğini göstermenin, uygulama iyi gitmiyorsa vazgeçmenin disiplin problemlerini çözmede kullandıkları başlıca yollar olduğu yönünde görüş bildirmişlerdir

Araştırma kapsamındaki okul yöneticileri disiplini sağlama adına en çok Öğretmenlerin problem çözümünde işbirliği ve katkı sağlaması görüşünde olduğunu belirtmişlerdir. Öyle ki, katılımcıların \%88'i ( $n=22)$ bu durumun etkili olduğu yönünde görüş belirtmişlerdir. Yöneticiler öğretmenlerin görev ve sorumluluklarını yerine getirmesinin ve sorunların çözümünde katkı sağlamalarının okulda disiplin sağlama adına olumlu bir durum olduğu görüşündedirler. Bu konuyla ilgili olarak şunları ifade etmişlerdir:

Nöbet ve ögrretmenlerde sıkıntı yok. Herkes nöbet tutar. Sorunları bize en sonda getiriyorlar. Ellerinden gelen her yöntemi deniyor. En son bize ıslah için getiriyorlar (Y10) Ögretmenler de yeterince yardımcı oluyor. Bir okul disiplinli olmazsa öğretmenler de kendini güvende hissedemezler (Y17)

Öğretmenler disiplin kurulunda görevleri varsa yerine getirirler. Bunun dışında ögretmenler nöbet görevlerini yerine getirir. Tabi biz de onlara yardımcı oluyoruz.(Y9)

Görev ve sorumlulukların paylaşılması ve okulda daha disiplinli bir ortamın oluşturulabilmesi için yöneticiler öğretmenlerin kendileriyle işbirliği içinde olması ile ilgili olarak da şunları dile getirmişlerdir:

Öğretmenlerle birlikte çözdügümüz problemler kolay. Sorunların çoğunluğunu bu sayede çözüyoruz. (Y6)

Idare ile ilgili karşlıklı güven var. Onlar idareye güveniyorlar. Herhangi bir sorun olduğunda zarar görmüyorlar. Bu yüzden de çocuklarla ilgili yaşanan sorunlar olduğunda da olayların üstüne çekinmeden gidebiliyorlar. (Y19)

Okul ögretmenlerimizin kalitesiyle yürüyor. Öğretmenlerin kaliteli olması ortada herhangi bir sorun olmamasını sağlıyor.(Y16)

Araştırmaya katılan okul yöneticileri öğrencilerin olumsuz davranışları olduğunda sorunu anlama, çözme ya da öncesinde sorunların yaşanmaması için ön önlem olarak rehberlik servisinden yararlanmaktadır. Yöneticilerin \%72'si $(n=18)$ rehberlik servisine sorunların çözümü için öğrencilerin yönlendirildiğini ifade etmişlerdir. Bu konu ile ilgili yöneticiler şunları dile getirmişlerdir:

Öğrencileri rehberlik etkinlikleri ile kazanmaya çalışıyoruz. (Y17, Y18)

Genel disiplin için sene başında rehberlikçe disiplin yönetmeliği izah ediliyor. (Y20)

Öğrencilerimizin davranışlarıyla ilgili olarak dikkatli bir izlemeye, takibe ve rehberlik anlayışına ve uygulamasına sahip olduğumuzdan rehberlik servisini etkin bir şekilde kullanıyoruz. Okul yönetimine başvurulduğu zaman, okul yönetimi de yönetmeliğe göre veya pedagojinin de gereği olarak öğrencileri rehberlik servisine uzman arkadaşlarımıza sevk ediyoruz (Y15).

Okullar sınıf adı verilen birimlerde öğrencilere olumlu davranışlar ve gerekli bilgi ve beceriyi sağlama görevini yürütmektedir. Bu süreçte sınıf rehber öğretmenlerinin öğrenci davranışlarını gözlemleme ve düzeltmede önemli bir role sahip olduğu söylenebilir. Öyle ki sınıf rehber öğretmenleri kendi sınıflarındaki öğrencileri daha kolay tanıma imkanına sahiptirler. Okul yöneticilerinin \%52'si $(n=13)$ sınıf rehber öğretmeninin çalışmalarının önemli derecede etkili 
olduğunu ifade etmektedir. Bu anlamda sınıf rehber öğretmenlerinin çalışmaları yöneticiler tarafından önemsenen diğer bir husustur. Yöneticilerin bu konudaki görüşleri aşağıdaki gibidir: Sık sık sınıf rehber ögretmenlerimiz veli toplantıları düzenliyor. Sınıfla ilgili kararlarda rehber ögretmeninden görüş̧ alıyoruz.(Y1)

Okul toplu yaşanan yer. Herkesin yaşam hakkı var. Bunları telkin ediyor, saygının vazgeçilmez bir değer olduğunu vermeye çalışıoruz. Sinıfta rehber öğretmenler velilere ve ögrencilere toplantı ve seminerler düzenliyor (Y10)

Bir sorun yaşandığında sınıf ögrretmeni öğrencilerle görüşür. Sonra velileri çağırarak durum hakkında bilgi verir. (Y21)

Sınıf ögretmenlerinden ögrencilerin sorunları dinlemelerini ve not almalarını isterim. Ögrretmen ögrrenciyle Gazi Parkında çay içer. Çocuklarla birebir görüşmeler sürdürülür. Gözlemler yapar. Veliye de el altından durum bildirilir. (Y11)

\section{Düzeltici Disiplin Yaklaşımı}

"Düzeltici Disiplin Yaklaşımı" teması altında ise, olumsuz davranışla ilgili veliyi bilgilendirmenin, disiplin cezası vermenin, disiplin ile ilgili kurulu toplamanın, yapılan olumsuz davranışla ilgili öğrencilerle konuşup sorunu anlamaya çalışmanın, cezaya en son yöntem olarak başvurma, öğrencileri yapmış olduğu davranıştan dolayı sözlü olarak uyarmanın, emniyet güçlerinden destek alınmasının, aralarında çatışma olan öğrencileri uzlaştırmanın ve azarlamanın okul yöneticiler tarafından başvurulan uygulamalar olduğu anlaşılmaktadır.

Düzeltici bir önlem olarak okul yöneticilerinin \%84'ü $(n=21)$ okulda yaşanan disiplin sorunlarıyla baş etmede Olumsuz davranışla ilgili veliyi bilgilendirme yaklaşımına başvurduklarını ifade etmektedir. Öğrencinin olumsuz bir davranışı olduğunda velinin haberdar edilmesi önleyici uygulama olarak en çok başvurulan durumdur. Bu konu ile ilgili yöneticiler şunları dile getirmişlerdir.

Rehberlikte veli uyarllyor, eğer olumsuz davranışı tekrar yaparsa cezaya başvururuz (Y24, Y22)

Herhangi bir disiplin sorunu olduğunda velileri durumla ilgili bilgilendiririz. Anlaşmazlıklarda öğrencileri barıştıracak, ailenin uzlaştırılacağı bir ortam oluştururuz. Çok ciddi bir durum var ise de tüm öğretmenler bir araya gelip veliyle toplanıyor. Veliye bilgi veriyoruz. Böylece çocuk velinin yanında yaptığı davranışı inkar edemiyor. Ailelerin olaya dahil olmasını sağlıyor, sözlerini alıyoruz(Y10)

Okul yöneticileri disiplini sağlama adına Disiplin Cezası Vermeyi de bir alternatif yol olarak kullanmaktadır. Araştırmaya katılan okul yöneticilerinin \%64'ü $(n=16)$ cezaya başvurduklarını belirtmişlerdir. Bu konudaki yönetici görüşleri aşağıda verilmiştir:

Yıllık 20-30 arası konuyu disiplin kurulunda görüşüyoruz, buna göre cezaya başvuruyoruz. Fakat bu aşamaya gelmeyen bir bu kadar daha olay var. (Y17) Öğretmen, ögrenci vb. tarafından şikayet olursa disiplin kurulu toplanır, suçun niteliğine göre önce uyarı verilir, sonra kınama cezasına döner. Okuldan uzaklaştırma ise ilçe disiplin kuruluna sevkedilir. Burada herkese eşit davranullyor. (Y9)

Ögrenci istenmeyen, olumsuz bir davranış sergilediğinde ceza alacağını biliyor. Okulumuzda sıkı bir disiplin anlayışı olan bir yönetim ekibi var. Okulumuzda cep telefonu yasak. Sigara içme cezası da veriyoruz. Öğrencilerin sigara içmeleri durumunda para cezası uyguluyoruz (Y19)

Okul içerisinde disiplinli bir ortam oluşturmak üzere yöneticilerin \% 56'sı (n=14), disiplin sorunları ortaya çıktığında disiplin ile ilgili kurulu toplama eğilimindedir. Bu kurul ortaokullarda Öğrenci Davranışları Değerlendirme Kurulu, liselerde ise Disiplin Kurulu olarak adlandırılmaktadır. Disiplin kurulunun toplanması süreçleriyle ilgili yönetici görüşleri aşağıda verilmiştir:

Suç unsuru varsa disiplin kurulu işletmeye gayret gösteriyoruz. (Y18) 
Öğretmen öğrenci vb. şikayet olursa disiplin kurulu toplanır, suçun niteliğine göre önce uyarı verilir. Okuldan uzaklaştırma ise ilçe disiplin kuruluna sevk edilir. Burada herkese eşit davranilıyor. \%90 disiplin kuruluna sevk edilme korkusu var. (Y9)

Öğrenci davranışları değerlendirme kurulumuz var. Öğrenci olumsuz davranışa devam ederse yaptığı davranışa uyarma ve kınama veririz. (Y17)

Araştırmaya katılan okul yöneticilerinin \%48'i $(n=12)$ disiplin sorunlarını çözmede cezaya en son yöntem olarak başvurduklarını ifade etmişlerdir. Bu konudaki yönetici görüşleri aşağıda verilmiştir:

Öncelikle öğrencilerimize telkin ve uyarılarda bulunuyoruz. Disiplin yönetmelikle değil, özel tedbirlerle halledilebilir. Herşeyi yönetmelikle çözemeyiz. Yönetmelik sadece bize yetki verir. Yöneticinin insiyatifi ve algısı önemli. (Y5)

Okulumuzda ciddi sorunlar yok. Önlem almazsan olmaz, olaylara anında müdahale ediliyor. Ama en son başvurulan çare yönetmelik. Amacımız herkese eşit davranmak. Buradaki ögrenciler dokunduğunda düzeliyor. En sorunlusu bile laf söz dinliyor.(Y14) Ögrencilerle görüş̧me yöntemiyle olumsuz davranışları yok etmeye çalışıoruz. Altı rehber ögretmenimiz var, sürekli çocukların ailelerini bilgilendiriyor. Bu yıl disiplin cezası verdiğimiz ögrenci yok. En son ihtimal olarak aileyi çağırıp sözleşme imzalatıyoruz. Milli eğitime gönderilen vaka yok. Ufak tefek olaylar olmuyor değil fakat biz olayların üstüne giderek olaylar büyümeden atlatıyoruz. (Y4)

Yaptırımla bir şey çözülmüyor. Diyalogla olmalı. Buradaki velilerin eğitim seviyesi düşük, dolayısıyla sorunları şiddetle çözmeye çalş̧ıorlar. Ceza vermek, tehdit, öğrencinin ve velinin umurunda değil. Olumlu iletişim kanalları oluşturarak ancak sorunlar çözülebilir (Y1)

Sınıf yönetiminde başvurulan disiplin yaklaşımları olarak önleyici, destekleyici ve düzeltici disiplin yaklaşımları bu araştırmada yöneticilerin disiplini sağlama adına başvurdukları uygulamaları temalaştırmak için kullanılmıştır. Öğretmenlerin sınıfta karşılaştıkları istenmeyen davranışlara yönelik başvurdukları yaklaşımlar öğretme- öğrenme sürecinde istenmeyen davranışların yaşanmaması, ya da yaşandığı takdirde bu sürece etki etmemesi açısından önem arz etmektedir. Sınıfta sürecin işlerliğini öğretmenin sağladığı gibi, okulda da okulun amaçlarına uygun şekilde yürütülmesinin sağlayıcısı okul yöneticisidir. Okuldaki eğitim-öğretim sürecinin yöneticisi olan okul müdürleri ve müdür yardımcıları bu sürecin sekteye uğramasına neden olabilecek eylemlere müdahalede farklı yaklaşımlar sergilemektedir. Yapılan bir araştırmada disiplin problemlerinin oluşmasında yönetimin tutumunun da etkili olduğu sonucuna ulaşılmıştır (Öz ve Sadık, 2015). Diğer bir çalışmada Çimen (2010), okul müdürlerinin disiplin dışı davranışları önlemede liderlik davranışlarının etkili olduğunu göstermektedir.

Araştırmaya katılan okul yöneticilerinin görüşleri daha çok önleyici disiplin yaklaşımına ilişkin temada yoğunlaşmıştır. Bu durum, okul yöneticilerine göre, okullarda disiplin problemlerinin meydana gelmesini engelleyici önlemlerin alınmasının okulda disiplini sağlama adına olumlu bir ortam oluşturmada etkili olduğunu göstermektedir. Green'in (2006) öğrenci merkezli önleme stratejilerinin yönetim stratejileri kadar etkili olduğunu ifade etmektedir.

Okul yöneticileri en çok okul veli ilişkisini güçlendirmenin, sosyal ve sportif etkinlikler düzenleyerek öğrencilerin katııımını teşvik etmenin ve sorunlar ortaya çıkmadan önce önlem almanın okulda disiplin sorunlarını önleyebilecek durumlar olduğunu ifade etmektedir. Duran (2011), okul müdürlerinin okul yönetimine yansıyan disiplin sorunlarını çözmede en çok, öğrenciye pozitif yaklaşım, öğrenci velileriyle ilişkileri etkili kılma, çevre unsurlarını etkili kılma, sosyal, kültürel, sportif faaliyetleri etkili kılma yaklaşımlarını benimsediklerini ifade etmektedir. Öz ve Sadık (2015) disiplin sorunlarının çözümünde, çocukların sağlıklı gelişimi için ailelerin bilinçlendirilmesi gerektiğini ve öğretmen ve ailelerin öğrencileri ve arkadaş çevrelerini daha yakından tanıma, ne yaşadıklarını ve hissettiklerini anlamaları için bir araya gelebileceği toplantılar düzenlenmesi gerektiğini ifade etmektedir. 
Bununla birlikte insanın yaşadığı her yerde olduğu gibi okullarda da çatışma ve anlaşmazlıkların olması kaçınılmazdır. Bu anlamda okul yöneticilerinin başvurdukları destekleyici ve düzeltici uygulamaların da güçlü bir okul kültürü oluşturma da önem arz etmektedir.

Araştırmaya katılan okul yöneticilerinin görüşleri destekleyici disiplin yaklaşımı boyutunda en çok, öğretmenlerin problem çözümünde işbirliği ve katkı sağlamasının, rehberlik servisinden destek alma ve sınıf rehber öğretmeninin çalışmaları görüşlerinde yoğunlaşmıştır Öz ve sadık (2015) rehberlik servisi aracılığıyla velilere ergen psikolojisi, disiplin, aile içi iletişim, okul ve kuralları vb. yönünde eğitici bilgiler verilmesinin faydalı olacağını ifade etmektedir. Duran (2011), okul müdürlerinin okul yönetimine yansıyan disiplin sorunlarını çözmede rehberlik hizmetlerinden destek alma yaklaşımlarını benimsediklerini ifade etmiştir.

Düzeltici disiplin boyutunda ise yönetici görüşleri olumsuz davranışla ilgili veliyi bilgilendirme, disiplin cezası verme disiplin ile ilgili kurulu toplamada yoğunlaşmıştır. Sarpkaya (2005), disiplin konusunda alınan önlemler konusunda; dışsal denetim odaklı önlemleri vurgulamıştır. Sorunlarla karşılaşıldığında yapılanlar konusunda, cezalandırıcı ve uyarma, öğüt verme gibi dışsal denetim odaklı baş etme yöntemleri ön plana çıkmaktadır.

Araştırmaya katılan okul yöneticilerine okul disiplinini sağlama adına başvurduğu uygulamalarla ilgili olarak sadece kendilerine özgü bir uygulamaları olup olmadığı sorulmuştur. Bu konuda, yöneticilerin başvurdukları uygulamalar Tablo 3'te verilmiştir.

Tablo 3. Okul disiplinini sağlamada başvurulan özgün uygulamalar

\begin{tabular}{|c|c|c|}
\hline Değişken & Ortaokul & Lise \\
\hline Öğrenci Koçluğu /Danışman öğretmenlik & $\mathrm{X}$ & $\mathrm{X}$ \\
\hline Zararlı alışkanlıklarla ilgili bilgilendirme Cd'lerinin izlettirilmesi & $\mathrm{X}$ & \\
\hline Öğrencilere yönelik okuma saatleri & $\mathrm{X}$ & \\
\hline Müdürün defteri & & $\mathrm{X}$ \\
\hline Öğretmenlere iletişim becerileri ve sınıf yönetimi ile ilgili seminerler & & $\mathrm{X}$ \\
\hline Öğrencilere yönelik sorumluluk projeleri & & $\mathrm{X}$ \\
\hline Sınavlarda kelebek sistemi & & $\mathrm{X}$ \\
\hline Öğrenci velilerine yıl başındaöğrencileri tanıma adına anket yapılması & $\mathrm{X}$ & \\
\hline Velilere okuma yazma kursu düzenleme & $\mathrm{X}$ & \\
\hline Öğrenci ve öğretmenlere memnuniyet anketi $X$ & & $\mathrm{X}$ \\
\hline Ailesi sorunlu öğrenciye psikolojik destek sağlama & & $\mathrm{X}$ \\
\hline Genel aramalar & & $\mathrm{X}$ \\
\hline Şikayet kutuları & & $\mathrm{X}$ \\
\hline Ailevi, sağlık ve özelliklerle ilgili öğrenci listesi oluşturma & $\mathrm{X}$ & \\
\hline Öğrencileri karar alma sürecinde aktif rol verme & & $\mathrm{X}$ \\
\hline Okul servisinin öğrencileri okul içinden alması & & $\mathrm{X}$ \\
\hline Sınıf panolarında okul kurallarıyla ilgili bilgilendirme yapılması & & $\mathrm{X}$ \\
\hline Sorunlu öğrencileri sınıflara serpiştirme & $\mathrm{X}$ & \\
\hline Öğretmenlerin teneffüslerde öğrencilerin arasında dolaşması & $\mathrm{X}$ & \\
\hline
\end{tabular}

Yöneticilerin çalıştıkları okullardaki kendilerine özgü disiplin uygulamalara bakıldığında daha çok sorunların meydana gelmesini önleyici yaklaşımların benimsendiği anlaşımaktadır. Disiplin problemlerinin çözümünde tek ve basit bir yol yoktur. Kaldı ki, okullar, okullarda yaşanan olaylar birçok açıdan farklılık gösterebilmektedir. Bu nedenle yaşanan sorunlar okulun içinde bulunduğu koşullar göz önünde bulundurularak değerlendirilmelidir. Bu açıdan okul müdürlerinin kendine özgü olarak başvurdukları bu uygulamalar kendi koşulları içinde değerlendirilmelidir. Ancak, yine de farklı yöntem ve uygulamaların bilinmesi diğer yöneticilere karşılaştıkları disiplin problemlerinde daha farklı bakış açıları kazandırabilir.

Araştırmaya katılan okul yöneticilerinin disiplin sorunlarını çözümlemede başvurdukları kendilerine özgü uygulamalara ilişkin yönetici görüşleri aşağıda verilmiştir:

Öğrenci Koçluğu /Dantşman öğretmenlik: Okulumuzda öğrenci koçluğu sistemini uyguluyoruz. Görevlendirdiğimiz her öğretmen öğrencilerin takip ve rehberliğini sağllyor. Sinemaya götürüyor, beraber bir takım sosyal etkinliklerde bulunuyor (Y10).

Danışman ögrretmenlik sistemimiz var. Her 15 ögrenciye 1 öğretmen. Yakın takip var. Maddi ve manevi destek (Y23). 
Zararlı alışkanlıklarla ilgili bilgilendirme Cd'lerinin izlettirilmesi: Öğrencilerimize zararlı alışkanlıklarla ilgili bilgilendirme yapıyoruz. Örneğin her sınıfa Sigaranın gerçek Yüzü adlı bir CD izlettik (Y5).

Öğrencilere yönelik okuma saatleri: Öğrenciler ve velilerle işbirliği yaparak okuma alışkanlığ kazandırma adına her hafta bir kitap okutma, okulda bunu bir komisyonun takip etmesi, sınav yapması ve performansa yansıtması şeklinde bir uygulamamız var. Sınıfın tamamı aynı kitabı okuyor. Alışkanlık kazandırma, akademik başarıyı arttırma, konuşma, hitabeti arttırma konusunda faydalı olduğunu düşünüyoruz (Y5).

Müdürün defteri: Kendime has, her sene için tuttuğum bir defterim vardır. Sorunları buraya not ederim. Okulda müdürün defterini herkes bilir. Okul içi ve dışı öğrencileri takip ederim. Bu deftere yaptıkları olumsuz davranışları kaydederim. Tüm bilgilerini toplar öğrenciyi çağırırım. Daha sonra bir olumsuz davranışı olursa öğrencinin, defterde kaydı varmı ona bakar ve durumu değerlendiririm (Y2O).

Öğretmenlere yönelik seminerler: Mesleki çalışma dönemlerinde özellikle eğitimde iletişim konusunda ilgili öğretmenimizi görevlendirerek bir seminer düzenledik. İletişimi bu manada mesleki çalışmada ele almamızın sebebi, biz öğretmenler olarak öğrenciye karşı olan davranışlarımızda gereken dikkati göstermememiz icap eder. Ama burada eğitimciye ögrretmene yöneticiye düşen görev en kolay yöntemle empati yapması meseleyi doğru çözümlemede ilk adım olabilir. Bu açıdan seminerin faydalı olduğunu düşünüyorum (Y15).

Öğrencilere yönelik sorumluluk projeleri: Bu yıl 4-5 sorumluluk projesi çıkardık. Ögrrenciler toplumsal fayda anlamında bir şey yapınca çocuk kendini ortaya koyabiliyor, kendini değerli hissediyor (Y16).

Sınavlarda kelebek sistemi: Sınavları tek bir haftaya yayıyoruz.Tüm sınıfları karıştırıyoruz, ve aynı anda sınavları yürütüyoruz. Kopyayı engellemek için aynı sınav salonunda 9,10, 11 ve 12. Sinffların hepsini karışık şekilde oturtuyoruz (Y16)

Öğrenci velilerine yılbaşında öğrencileri tanıma adına anket yapılması: Ögrencilerin velilerine dönem başında bir anket yaparı. Kendi fotoğraflarını görebilmeleri ve biz görelim diye. Öğrenci fotoğrafını gördükten sonra, sınıf öğretmeni, rehber öğretmen ve muavinler elimizdeki malzemeyi tanımaya çalışırı. Konu başlıklarına, sorunlara göre durumu belirler, beş rehber ögretmen altı muavine bölüştürürüm. Sorunları dinlemelerini ve not almalarını isterim. Ne kadarı çözülebilir maddi manevi ona bakar ve ona göre eğitim veririz (Y11).

Öğrenci ve öğretmenlere memnuniyet anketi: Öğrenci ve ögretmenlere memnuniyet anketi yapıyoruz. Yöneticiyi okulu değerlendiriyorlar. Böylece artı ve eksilerimizi görüp, ona göre süreçlerimizi düzenliyoruz (Y13).

Genel aramalar: Okul disiplin kurulu kararıla genel aramalar yapıyoruz (Y20).

Şikayet kutulart: 3 günlük süre içinde geri kaldırmak üzere okulun belirli yerlerine şikayet kutuları yerleştiriyoruz (Y21).

Ailevi, sağlık vb. özelliklerle ilgili öğrenci listesi oluşturma: Ailevi sorunu olan öğrenciler, sağlık sorunu olan öğrenciler listesi tutarım. Öğrencinin hangi koşullardan geldiğini bileceksin. Bu sayede maddi durumundan dolayı bazı çocukların masraflarını karşıllyoruz (Y11).

Öğrencileri karar alma sürecinde aktif rol verme: Okul meclisini işletiyoruz. Okul temsilcileri aylık toplantılar yapıyor, sorunları bize dile getiriyor, öneri sunmalar konusunda teşvik ediyoruz. Yemekhane yemek listesini gıda mühendisleri, okul hemşiresi denetiminde ögrrenciler kendileri hazırlyyorlar. İstemedikleri yemeği vermiyoruz (Y13).

Sorunlu öğrencileri sınıflara dağıtma: Biz de sorunlu öğrencileri sınıflara serpiştiriyoruz. Böylece olumsuz davranışı söndürüyoruz (Y4).

Öğretmenlerin teneffüslerde öğrencilerin arasında dolaşması: Öğretmenlerimiz öğretmenler odasında oturmazlar. Genelde öğrencilerin arasında bahçede sohbet ederek teneffüslerini geçirirler. Böylece çocuk çevresinde büyüklerinin olduğunu görerek davranışları konusunda kendilerine çeki düzen veriyorlar (Y2). 


\section{SONUÇ VE ÖNERILER}

Okul yöneticileri yaşanan disiplin problemlerine müdahalede farklı yaklaşımlar sergilemektedir. Disiplin sorunları ile ilgili olarak okullarda başvurulan uygulamalara ilişkin okul yöneticilerinin görüşlerinin Önleyici, Destekleyici ve Düzeltici Disiplin Yaklaşımları olmak üzere üç tema altında toplandığı görülmektedir. Bu bulgu okul yöneticilerinin, disiplin sorunlarının yaşanması sürecinde önleyici uygulamaların, destekleyici uygulamaların ve düzeltici uygulamaların etkili olabileceğini düşündüklerini göstermektedir. Araştırmada önleyici disiplin yaklaşımı" temasına uygun görüşlerin ağırlıkta olduğu görülmektedir.

Araştırmaya katılan okul yöneticilerinin görüşleri daha çok önleyici disiplin yaklaşımına ilişkin temada yoğunlaşmıştır. "Önleyici Disiplin Yaklaşımı" teması altında, okul veli ilişkisini güçlendirmenin, sosyal ve sportif etkinlikler düzenleyerek öğrencilerin katılımını teşvik etmenin, sorunlar ortaya çıkmadan önce önlem almanın, ayın sınıfı, ayın öğrencisi uygulamalarıyla öğrencileri motive etmenin, olumlu davranış sergileyen örnek öğrencileri ödüllendirmenin, özel güvenlik görevlisi istihdam etme uygulamalarının en çok başvurulan uygulamalar olduğu belirlenmiştir. Okul yöneticilerinin disiplini sağlama adına aldıkları önlemlerin sorunun ortaya çıkmasını engellemede etkili olduğunu düşündükleri belirlenmiştir.

Okullarda yaşanan disiplin problemlerinin okul yaşam kalitesiyle ilgili olduğu da söylenebilir. Öğrencilerin okulu algılama biçimleri, okulun onlara sunduğu olanaklar ve yaşam kalitesi öğrenci davranışları üzerinde etkili olmaktadır. Yöneticiler ve öğretmenler okullarını her açıdan sorgulamalı ve okulu geliştirmek ve öğrencilerin okula bağlıığını arttırmak için çaba göstermelidir.

Okullarda disiplini sağlama adına öğretmenlerin desteği ve işbirliği önem arz etmektedir. Davranış değiştirme sorumluluğunun öğretmende disiplin sorumluluğunun okul yöneticisinde olması (Toprakcı, 2008, 21) bu işbirliği ve desteğin engellerinden biri olabilir. Öğretmenin de yasal ve fiili olarak dahil olduğu bir yapıya ihtiyaç olduğu açıktır. "Destekleyici Disiplin Yaklaşımı" teması altında öğretmenlerin problem çözümünde işbirliği ve katkı sağlamasının, rehberlik servisinden destek almanın ve sınıf rehber öğretmeninin çalışmalarının en çok tercih edilen uygulamalar olduğu görülmektedir.

"Düzeltici Disiplin Yaklaşımı" teması altında ise, olumsuz davranışla ilgili veliyi bilgilendirmenin, disiplin cezası vermenin, disiplin ile ilgili kurulu toplamanın, yapılan olumsuz davranışla ilgili öğrencilerle konuşup sorunu anlamaya çalışmanın, cezaya en son yöntem olarak başvurmanın, öğrencileri yapmış olduğu davranıştan dolayı sözlü olarak uyarmanın en çok tercih edilen uygulamalar olduğu görülmektedir.

Okulda yaşanılan sorunlarla ilgili olarak veli bilgilendirilmelidir. Okul- veli ilişkisi güçlendirilmeli, velilerin okulla bağının koparılmaması gerekmektedir. Sorun yaratan öğrencilere disiplin cezası verilebileceği gibi, disiplin cezası vermeden de, tutarlı olmak kaydıyla, uyarılar yoluyla cezadan kaçınılabilir.

Yöneticilerin çalıştıkları okullardaki kendilerine özgü disiplin uygulamalarına bakıldığında daha çok sorunların meydana gelmesini önleyici yaklaşımların benimsendiği anlaşılmaktadır. Araştırmaya katılan yöneticilerin çalıştıkları okullardaki kendilerine özgü disiplin uygulamaları şunlardır: Toprakcı (2012) nın adına "Sınıf Yöneticiliği/Koçluğu" dediği pratiktekilerin adlandırıldığı haliyle Öğrenci Koçluğu /Danışman öğretmenlik, Zararlı alışkanlıklarla ilgili bilgilendirme amaçlı görsellerin (CD) izlettirilmesi, Öğrencilere yönelik okuma saatleri, Müdürün defteri uygulaması, Öğretmenlere yönelik seminerler, Öğrencilere yönelik sorumluluk projeleri, Sınavlarda kelebek sistemi, Öğrenci velilerine yıl başında öğrencileri tanıma adına anket uygulanması, Öğrenci ve öğretmenlere memnuniyet anketi, Genel aramalar, Şikayet kutuları, Ailevi, sağlık vb. özelliklerle ilgili öğrenci listesi oluşturma, Öğrencileri karar alma sürecinde aktif rol verme, Sorunlu öğrencileri sınıflara dağıtma, Öğretmenlerin teneffüslerde öğrencilerin arasında dolaşması. 
Disiplin problemlerinin çözümünde tek ve basit bir yol yoktur. Kaldı ki, okullar ve okullarda yaşanan olaylar birçok açıdan farklılık gösterebilmektedir. Bu nedenle yaşanan sorunlar okulun içinde bulunduğu koşullar göz önünde bulundurularak değerlendirilmelidir. Ancak, yine de farklı yöntem ve uygulamaların bilinmesi diğer yöneticilere karşılaştıkları disiplin problemlerinde daha farkı bakış açıları kazandırabilir. Disiplin sorunlarının çözümüne ilişkin başvurulan uygulamalarla ilgili olarak Milli Eğitim Bakanlığı öğretmen ve yöneticilerin görüş ve önerilerini alabilir ve başvurulacak alternatif yolları içeren yaklaşımları bir kitapçık olarak okullara gönderebilir.

\section{KAYNAKÇA}

Ada, S., Çetin, (2006). Eğitim ve ögretim Ortamında Disiplin Nedir? İstanbul: Nobel Yayınları.

Başar, H. (1999). Sınıf Yönetimi. İstanbul: MEB Yayınları, Öğretmen Kitapları Dizisi.

Başar, H. (2014). Sınıf Yönetimi (19. Baskı). Ankara: Anı Yayıncılık.

Boynton, M. ve Boynton, C. (2007). Eğitimciler için disiplin sorunlarını önleme ve çözme rehberi. (Çev. Tülin Büyükalkan). İstanbul: Redhouse Eğitim Kitapları.

Butchart, R. E.,McEwan, B.(Ed). (1997). ClassroomDiscipline in American Schools.Albany, NY, USA: StateUniversity of New York Press.

Büyüköztürk, Ş., Çakmak, E. K., Akgün, Ö. E., Karadeniz, Ş. ve Demirel, F. (2010). Bilimsel Araştırma yöntemleri. (7.basım). Ankara: Pegem A Yayıncılık.

Cangelosi, J.S. (2016). Sınıf Yönetimi Stratejileri: Öğrencilerin İşbirliği yapmalarını sağlama ve bu işbirliğini devam ettirme. (Çev. R. Hoş, M.Toprak) (7 basımdan çeviri). Ankara : Nobel Akademik Yayınclık.

Celep, C.(2000). Sınıf Yönetimi ve Disiplini. Ankara: Anı Yayıncılık.

Esen, H. (2006). ilk ve Ortaöğretim Okullarında Görev Yapan ÖğretmenlerinKullandıkları Disiplin Türleri (Edirne Illi Örneği). Yayınlanmamış Yüksek LisansTezi, Edirne: Trakya Üniversitesi, Sosyal Bilimler Enstitüsü.

Deshmukh, A. V.,andNaik, Anju P. (2010). Educational Management. Mumbai: IND: Himalaya Publishing House.

Duran, O.C., (2011), Ortaöğretim kurumlarında okul yönetimine yansıyan disiplin sorunları okul yöneticilerinin çözüm yaklaşımları: Uşak ili örneği Yayınlanmamış Yüksek Lisans Tezi. Uşak Üniversitesi, Sosyal Bilimler Enstitüsü. Uşak.

Edwards, Clifford H.. (2011). DemocraticDiscipline in Learning Communities: TheoryandPractice. PA, USA: Rowman\&LittlefieldEducation.

Green, G. N. (2006). Teacherperceptions of schooldisciplinepolicies in a multi-school, publiccharterschoolcorporationandadministratorresponse. Yayınlanmamış Doktora Tezi. Universitiy of Wisconsin. Madison. http://search. proquest.com/docview/304981860? accountid=16268adresinden 21/08/2016 tarihinde indirilmiştir.

Güven, M., B. Dönmez, (2002). "Ortaöğretim Öğrencilerinin Okul Güvenliğine İlişkin Algı ve Beklentileri". Inönü Üniversitesi Eğitim Fakültesi Dergisi. 3 (4), 59-68.

Geylan, R. Ve Tonus, H.Z. (2013). Insan Kaynakları Yönetimi. Eskişehir: AnadoluÜniversitesi Yayınları, 2900.

Kohn, Alfie. (2006). Beyond Discipline : FromCompliancetoCommunity. 10th Anniversary Edition. Alexandria, VA, USA: AssociationforSupervision\&Curriculum Development (ASCD). ProQuestebrary Sitesinden 6 Eylül 2015 tarihinde indirilmiştir.

Mendler, Allen.(2007). What Do I Do When...? : How toAchieveDisciplineWithDignity in theClassroom. Bloomington, IN, USA: Solution TreePress.

Miles, M. B., andHuberman, A. M. (1994). Qualitativedataanalysis: An expandesourcebook (2nd edition). London: Sage.

Neuendorf, K. A. (2002). Thecontentanalysisguidebook.ThousandOaks, CA: Sage.

Öz, E,Z., F. Sadık. (2015). Ortaokul Öğretmenleri ve Öğrencilerinin Disiplin Problemleri ve Başetme Stratejilerine Yönelik Görüş ve Beklentileri. Akademik Sosyal Araştırmalar Dergisi, 3(18), 151-189.

Rogers, B. (2004). How toManageChildren'sChallengingBehaviour.London, GBR: SAGE Publications Inc.

Sarpkaya, P. (2005). Resmi Liselerde Disiplin Sorunları ve Ilgili Grupların (Öğretmen, Öğrenci, Yönetici, Veli) Yaklaşımları. Yayınlanmamış Doktora Tezi. Dokuz Eylül Üniversitesi Eğitim Bilimleri Enstitüsü, İzmir.

Şişman M., S. Turan, (2008). Sınıf Yönetimi (6. Baskı). Ankara: Öğreti, Pegem akademi

Tauber, Robert T.. (1999). ClassroomManagement : SoundTheory\&EffectivePractice. USA: GreenwoodPress. 
Toprakcı, E. (2008) Eğitimde Disiplin ya da Sınıfın Disiplini ilköğretmen Dergisi ISSN: 1307-1238 Sayı: 23. http://www.erdaltoprakci.com.tr/wp-content/uploads/2018/11/E\%C4\%9Fitimde-Disiplin-ya-daS\%C4\%B1n\%C4\%B1f\%C4\%B1n-Disiplini.pdf 21/08/2019 tarihinde indirilmiştir.

Toprakcı, E. (2012) Rethinking Classroom Management: A new perspective, a new horizon. e-international journal of educational research (e-uluslararası eğitim araştırmaları dergisi) 3(3), 84-110. https://eric.ed.gov/?id=ED538969 22/08/2019 tarihinde indirilmiştir.

Toprakcı, E. (2017) Sınıfa Yönetimi Ankara: PegemA Yayınları

Tosun Ü. (2002). Onurlu Disiplin, Beyaz Yayınları, İstanbul.

Türnüklü, A. (2006). Sınıf ve Okul Disiplinine Çağdaş Bir Yaklaşım: Onarıcı Disiplin, Ankara: Ekinoks Yayınları. Wolfgang, C.H. (2005). Solving Discipline and Classroom Management Problems. USA 6th Edition Wiley and Sons Inc.

Weber, R. P. (1990). Basic contentanalisys (2. Baskı). Newbury Park, CA: Sage.

Yıldırım, A. ve Şimşek, H. (2006). Nitel araştırma yöntemleri. Ankara: Seçkin Yayınevi. 


\title{
Administrative Practices for Overcoming Discipline Problems at Lower Secondary Schools and High Schools
}

\author{
Dr. Fatih Pehlivan \\ MEB-Turkey \\ fatihpehlivan@yahoo.com
}

\author{
Assoc.Prof.Dr. Hasan Demirtaş \\ Inönü University-Turkey \\ hasan.demirtas@inönü.edu.tr
}

\begin{abstract}
The aim of this study is to reveal the practices at lower secondary schools and high schools to maintain school discipline. For the study, the maximum variation sampling method was used. To that end, the study group consisted of 25 school administrators. The data of this study were collected by the way of semi structured interviews with the school administrators. The data was analyzed by using content analysis. In the light of the findings, it is found that school administrators believe that preventative, supportive and corrective discipline practices may be effective in solving discipline problems. In the study, preventative discipline measures are commonly seen to be adopted by administrators. Administrators mostly tend to overcome discipline problems by involving teachers in problem solving process and by informing the parents about the behavior.
\end{abstract}

Keywords: School discipline, Student discipline, Discipline problems, Approaches for preventing discipline problems,

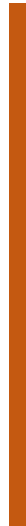

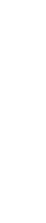

\section{of}

E-International Journal of Educational Research, Vol:x, No:x, 20xx, pp. $x-x$

DOI: 10.19160/ijer.584206

Received: 28.06.2019 Accepted: 20.08.2019

\section{Suggested Citation:}

Pehlivan, F. \&.Demirtaş, H. (2016). Administrative Practices for Overcoming Discipline Problems at Lower Secondary Schools and High Schools, E-International Journal of Educational Research, Vol: 10, No: 2, 2019, pp. 31-50, DOI: $10.19160 /$ ijer.584206 


\section{EXTENDED ABSTRACT}

Problem: All theories related to education aims to increase students' success at school by creating an appropriate learning environment. Achieving the desired learning aims and educational objectives depend on an educational environment where the students and the school staff feel themselves free and safe. In Turkish education system, schools where students obtain the target behaviors through teaching-learning processes have their distinctive features in terms of various internal and external factors. In this respect, discipline problems at schools, the reasons of these problems and the practices regarding the solutions vary because of a number of factors such as school environment, students, teachers, classroom etc.

In today's world, for the solutions of discipline problems at schools, sanctions are imposed according to the basis in regulations. Besides, to discuss and introduce the essence of disruptive behavior, the appropriateness and the effect of the punishment and the way to address the discipline problems at school are also of vital importance. This study aims to reveal different approaches for solving the discipline problems at schools. To that end, the practices of school administrators to maintain school discipline is discussed in the study.

Method: In this study, multiple case-holistic designs are used. For the study, the maximum variation sampling method, which is commonly applied in qualitative research studies, and that is thought to provide in depth analysis of the situations which might have substantial data, was applied.

To that end, the study group consisted of 25 school administrators who are school principals and vice principals. These administrators work at lower secondary schools with low, medium and high socio-economic status and Science and Social Sciences High Schools, Anatolian High Schools and Vocational and Technical High Schools.

The data of this study were collected by the way of semi-structured interviews with the school administrators. The data were analyzed and interpreted through content analysis. Within this scope, interview records that were converted to text were typed and checked in terms of spellcheck and grammar and coded. The data are presented by tables of the themes and direct quotations from the participants.

Results and Suggestions: School administrators show different approaches for the intervention in the discipline problems at schools. In the light of the findings, it is understood that the views of the administrators regarding the practices for solving discipline problems at schools are grouped under three themes which are preventative, supportive and corrective discipline practices. This data show that school administrators believe that preventative, supportive and corrective discipline practices may be effective in solving discipline problems.

In the study, preventative discipline measures are commonly seen to be adopted by administrators. Administrators believe that the precautions they took for maintaining school discipline are effective for preventing the problems before they occur. Most preferred practices under the theme of "preventative discipline approach" are communication between parent and school staff, organizing social and sports activities and encouraging students to participate them, best class, best student of the month, giving rewards to students, security guard.

It might be said that the discipline problems at schools are related to the quality of life at school. Students behaviors are effected by their perceptions about the school and the school facilities. Administrators and teachers should question their schools in all respects and should aim for developing the school and increasing the students' commitment to school. 
It is essential for administrators to have the support of the teachers and collaboration with them in order to maintain school discipline. Under the theme of "Supportive Discipline Approach", administrators mostly tend to overcome discipline problems by involving teachers in problem solving processes, by getting support from school counseling service and by the activities of advisor teacher informing the parents about the behavior.

"Corrective discipline approach" theme includes practices such as; informing parents about the disruptive behavior, imposing sanctions, gathering discipline committee, trying to understand the problem by talking to the student about the unwanted behavior, inflicting disciplinary punishment as the last method, warning student because of his/her behavior.

Distinctive discipline practices of the administrators at schools where they work are seen to be relatively preventative. These distinctive discipline procedures of administrators in terms of maintaining discipline are; Student Coaching /Advisory, informing students about bad habits, free reading hours for students, the notebook of the principal, social responsibility projects for students, teacher-student satisfaction surveys, boxes of claims, organizing in-service training courses for teachers, butterfly method in exams, parent surveys at the beginning of the school year, engaging students in decision making processes.

There is no single and ideal way for solving the discipline problems. Moreover, schools and problems experienced at schools vary in many ways. So, the problems should be considered by taking schools circumstances into account. However, to be aware of different method and approaches might help administrators to find different point of views in solving discipline problems. 